\title{
Isolation and characterization of a single-stranded DNA virus infecting the marine planktonic diatom Chaetoceros sp. (strain TG07-C28)
}

\author{
Kensuke Toyoda $^{1,2}$, Kei Kimura ${ }^{1}$, NaOtsugu Hata ${ }^{3}$, Natsuko Nakayama ${ }^{1}$, \\ KeIZO NAGASAKI ${ }^{1}$ \& Yuji TOMARU ${ }^{1, *}$ \\ 1 National Research Institute of Fisheries and Environment of Inland Sea, Fisheries Research Agency, 2-17-5 Maruishi, \\ Hatsukaichi, Hiroshima 739-0452, Japan \\ 2 Present address: Research and Education Center for Natural Sciences, Keio University, 4-1-1 Hiyoshi, Kohoku-ku, \\ Yokohama, Kanagawa 223-8521, Japan \\ 3 Mie Prefecture Fisheries Research Institute, 3564-3 Hamajima, Hamajima, Shima, Mie 517-0404, Japan
}

Received 19 August 2011; Accepted 1 December 2011

\begin{abstract}
Diatom dynamics in the ocean represents one of the most interesting research themes for marine ecologists. Recent studies have shown the significance of viruses as potential sources of mortality for diatom populations, as well as the more traditional environmental factors. Here, we report the isolation and characterization of a new single-stranded DNA (ssDNA) virus (Csp05DNAV) that causes lysis in Chaetoceros sp. TG07-C28, isolated from the surface water of Ago Bay, Japan. The virus was isolated from the sediments in Ago Bay, and its infection was both lytic and species-specific. The latent period was estimated to be $<24 \mathrm{~h}$. The virion is $32-34 \mathrm{~nm}$ in diameter, and accumulates in the nucleus of host cells. Csp05DNAV has a closed circular ssDNA genome, which includes a partially double-stranded region. Partial sequence analysis revealed that the open reading frame of this virus genome was similar to the putative replicase-related proteins of previously reported diatom viruses that harbor a ssDNA genome; specifically, CsalDNAV, CdebDNAV, ClorDNAV, and CtenDNAV. Based on the genome structure, Csp05DNAV is considered to belong to the genus Bacilladnavirus. As both the host and virus were isolated from Ago Bay, the host-virus system probably is ecologically important in the bay. This finding provides basic information towards elucidating diatom dynamics in coastal waters.
\end{abstract}

Key words: Bacilladnavirus, Chaetoceros, diatom, rod-shaped particle, ssDNA

\section{Introduction}

Diatoms (Bacillariophyceae) are one of the most abundant groups of photosynthetic microorganisms in the ocean, and account for a large part of marine primary production (Nelson et al. 1995, Kooistra et al. 2007). Among this group, the genus Chaetoceros is highly diverse, with more than 400 species functioning as key primary producers that sustain higher forms of aquatic life. In fact, Chaetoceros has been described as the most dominant phytoplankton group of the ocean (Rines \& Hargraves 1988). Therefore, within the framework of marine ecological studies, it is important to understand the dynamics of diatoms, including those belonging to the genus Chaetoceros.

\footnotetext{
*Corresponding author: Yuji Tomaru; E-mail, tomaruy@affrc.go.jp
}

While various environmental factors that are considered to affect diatom dynamics have been reported (Geider et al. 1988, Sarthou et al. 2005), recent studies have shown the potential significance of viruses in controlling the population dynamics of diatoms in natural environments (Tomaru et al. 2011a).

Diatom viruses are now represented by two recently approved virus genera, Bacillarnavirus and Bacilladnavirus (International Committee on Taxonomy of Viruses, http:// talk.ictvonline.org/), and several uncategorized members. The genera Bacillarnavirus and Bacilladnavirus comprise diatom viruses with a linear single-stranded RNA (ssRNA) genome and a circular single-stranded DNA (ssDNA) genome, respectively. Some diatom viruses have a genome type or structure that has not been sufficiently elucidated, and await categorization. All diatom viruses specifically 


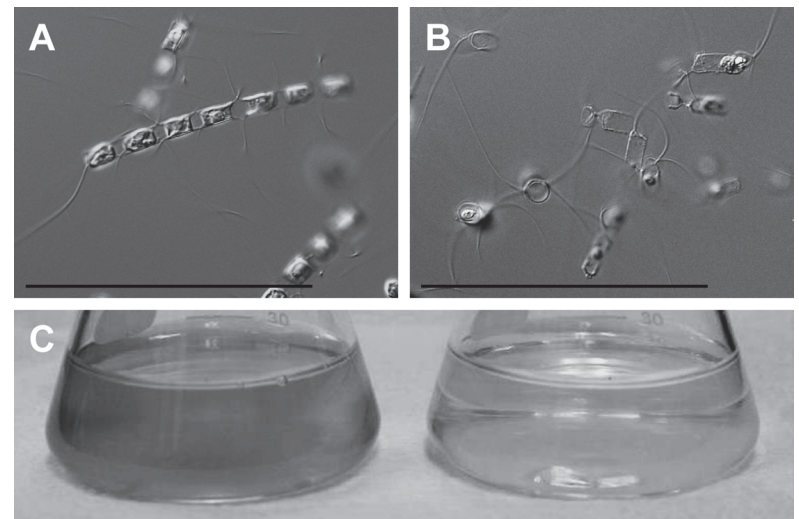

Fig. 1. Chaetoceros sp. strain TG07-C28. (A) Optical micrograph of intact cells. (B) Optical micrograph of Csp05DNAV-infected cells at $48 \mathrm{~h}$ post-inoculation. Bars indicate $100 \mathrm{~mm}$. (C) Chaetoceros sp. cultures of control (left) and added Csp05DNAV (right), 4 days post-inoculation.

lyse their respective host diatom species; therefore, they are supposed to represent an important controlling agent for the dynamics of their respective host populations.

Although knowledge about the species and ecological characteristics of diatom viruses is gradually accumulating, it is insufficient to understand the population dynamics of diatoms in natural waters. In the present report, we introduce a new circular ssDNA diatom virus that infects Chaetoceros sp. strain TG07-C28, where both the host and the virus were isolated from Ago Bay, Japan.

\section{Materials and Methods}

\section{Algal cultures and growth conditions}

The axenic clonal algal strain used for virus isolation in this study was Chaetoceros sp. strain TG07-C28 (Fig. 1). The strain was isolated from the surface water of Ago Bay $\left(34^{\circ} 17.643^{\prime} \mathrm{N}, 136^{\circ} 49.899^{\prime} \mathrm{E}\right)$, Japan, on July 4, 2007. Ago Bay is located in a semi-enclosed area in a water depth of ca. $10 \mathrm{~m}$. Algal cultures were grown in modified SWM3 medium that was enriched with $2 \mathrm{nM} \mathrm{Na}_{2} \mathrm{SeO}_{3}$ (Chen et al. 1969 , Itoh \& Imai 1987) under a 12/12 h light-dark cycle of ca. 110 to $150 \mu \mathrm{M}$ of photons $\mathrm{m}^{-2} \mathrm{sec}^{-1}$, using cool white fluorescent illumination at $15^{\circ} \mathrm{C}$. The species of Chaetoceros sp. strain TG07-C28 is considered to be different from the diatom host species of the viruses reported to date, according to analyses of PCR-restriction fragment length polymorphisms targeting the ribulose-1,5-bisphosphate carboxylase/oxygenase large subunit gene of chloroplast DNA (Toyoda et al. 2011). The species to which this strain belongs has not yet been determined based on its morphological features.

\section{Virus isolation}

Sediment samples $(0-1 \mathrm{~cm}$ depth) were collected from
Ago Bay, Japan, on October 26, 2008, using an EkmanBirge bottom sampler equipped with a $36 \mathrm{~mm} \phi$-corer tube (Yokoyama \& Ueda 1997). Collected samples were delivered to the laboratory without fixation within $24 \mathrm{~h}$ of sampling, and stored at $4^{\circ} \mathrm{C}$. Three grams of the sediment sample were shaken with $3 \mathrm{~mL}$ of $\mathrm{N}_{2} \mathrm{SeO}_{3}$-enriched SWM3 ( $400 \mathrm{rpm}, 23^{\circ} \mathrm{C}$, for $30 \mathrm{~min}$ ), and centrifuged at $860 \times g$ at $4^{\circ} \mathrm{C}$ for $10 \mathrm{~min}$. The supernatants were then passed through $0.2 \mu \mathrm{m}$ Dismic-25cs filters (Advantec MFS Inc., Tokyo, Japan). Aliquots $(0.2 \mathrm{~mL})$ of the filtrates obtained from sediment samples were inoculated into exponentially-growing Chaetoceros sp. TG07-C28 cultures $(0.8 \mathrm{~mL})$, followed by incubation at $15^{\circ} \mathrm{C}$ using the light/dark cycle conditions described above. Algal cultures inoculated with SWM3 served as controls.

From the cultures that showed an apparent crash in host cells after inoculation of the filtrates (e.g., Fig. 1), the responsible pathogens were cloned through 2 extinction dilution cycles (Suttle 1993, Tomaru et al. 2004). Briefly, the algal lysate was diluted in modified SWM3 medium in a series of 10 -fold dilution steps. Aliquots $(100 \mu \mathrm{L})$ of each dilution step were added to 8 wells in cell culture plates with BD Falcon 96 flat-bottom wells (Becton, Dickinson and Company, Tokyo, Japan) containing $150 \mu \mathrm{L}$ of an exponentially growing host culture. Then, the algal lysate in the most diluted well of the first assay was carried over to the second extinction dilution procedure. Finally, the resultant lysate in the final end-point dilution was used as a clonal lysate, in which the probability of two or more viruses occurring (i.e., failure in cloning) was estimated at $<0.0106$. Bacterial contamination was removed from each lysate in the highest dilution well of the second assay by filtration through a $0.1 \mu \mathrm{m}$ polycarbonate membrane filter (Whatman Ltd., Kent, UK), after which the lysate was transferred to another exponentially growing host culture. To confirm or refute bacterial contamination, each lysate was observed using epifluorescence microscopy, after staining with SYBR-Gold. Briefly, the lysate was fixed with glutaraldehyde at a final concentration of $1 \%$, and SYBR-Gold (Molecular Probes Inc., Eugene, OR, USA) was added to each fixed sample at a final concentration of $1.0 \times 10^{-4}$ dilution of the commercial stock. The stained samples were filtered onto a $0.2 \mu \mathrm{m}$ pore size polycarbonate membrane filter (Whatman Ltd., Kent, UK). Then, the filters were mounted on a glass slide with a drop of lowfluorescence immersion oil, and covered with another drop of immersion oil and a cover slip. The slides were viewed at a magnification of $\times 1000$ with an epifluorescence microscope (BX50, Olympus, Tokyo, Japan). The resultant axenic lysate was treated as a clonal virus suspension and used for further analyis.

\section{Host range}

The inter-species host specificity of the isolated virus clone was tested by adding $5 \%(\mathrm{v} / \mathrm{v})$ aliquots of fresh lysate that had been passed through a $0.2 \mu \mathrm{m}$ pore size polycar- 
Table 1. Infection specificities of Csp05DNAV against 28 strains of marine phytoplankton.

\begin{tabular}{|c|c|c|c|c|}
\hline Famiy & Species & Strain code & Temperature $\left({ }^{\circ} \mathrm{C}\right)$ & $\begin{array}{l}\text { Strains lysed by } \\
\text { Csp05DNAV }^{\mathrm{a}}\end{array}$ \\
\hline \multirow{14}{*}{ Bacillariophyceae } & Chaetoceros debilis & Ch48 & 15 & - \\
\hline & Chaetoceros tenuissimus & $2-10$ & 15 & - \\
\hline & Chaetoceros salsugineum & Ch42 & 15 & - \\
\hline & Chaetoceros socialis f. radians & L-4 & 15 & - \\
\hline & Chaetoceros cf. affinis & Ch5 & 15 & - \\
\hline & Chaetoceros lorenzianus & ItDia-51 & 15 & - \\
\hline & Chaetoceros sp. & TG07-C28 & 15 & + \\
\hline & Chaetoceros cf. pseudocurvisetus & IT07-C37 & 15 & - \\
\hline & Detonula pumila & IT09-K05 & 15 & - \\
\hline & Ditylum brightwellii & IT09-K19 & 15 & - \\
\hline & Eucampia zodiacus & EzB & 15 & - \\
\hline & Rhizosolenia setigera & S2 & 15 & - \\
\hline & Skeletonema sp. & IT09-K17 & 15 & - \\
\hline & Stephanopyxis sp. & IT09-K16 & 15 & - \\
\hline Eustigmatophyceae & Nannochloropsis sp. & SFBB & 20 & - \\
\hline Cryptophyceae & Teleaulax amphioxeia & Tel5W & 20 & - \\
\hline \multirow[t]{7}{*}{ Dinophyceae } & Alexandrium catenella & $\mathrm{ACNG}$ & 20 & - \\
\hline & Gymnodinium catenatum & GC27-1 & 20 & - \\
\hline & Heterocapsa circularisquama & HU9433-P & 20 & - \\
\hline & Heterocapsa triquetra & $\mathrm{Ht}$ & 20 & - \\
\hline & Karenia mikimotoi & GmH6 & 20 & - \\
\hline & Prorocentrum triestinum & Pt-1 & 20 & - \\
\hline & Scrippsiella sp. & SCKR & 20 & - \\
\hline \multirow[t]{5}{*}{ Raphidophyceae } & Chattonella antiqua & CaAR & 20 & - \\
\hline & Chattonella marina & CMKG-1 & 20 & - \\
\hline & Chattonella ovata & $\mathrm{CoV}$ & 20 & - \\
\hline & Fibrocapsa japonica & F96 & 20 & - \\
\hline & Heterosigma akashiwo & H93616 & 20 & - \\
\hline
\end{tabular}

a -, not lysed; +, lysed.

bonate membrane filter (Whatman Ltd., Kent, UK) to duplicate cultures of the following 28 exponentially growing clonal algal strains that belong to the families of Bacillariophyceae, Cryptophyceae, Dinophyceae, Eustigmatophyceae, and Raphidophyceae (shown in Table 1). The algal cultures were cultured under the conditions given above at either $15^{\circ} \mathrm{C}$ or $20^{\circ} \mathrm{C}$. Growth, cell condition, and evidence of lysis in each algal culture were monitored by optical microscopy, and compared against control cultures that were inoculated with SWM3. Algal lysis was scored when an aggregation of lysed cells was observed on the bottom of the culture vessels. Cultures that did not appear to be lysed at 14 days post-inoculation (dpi) were scored as unsuitable hosts for the viral pathogen.

\section{Virus purification}

A $450 \mathrm{~mL}$ exponentially growing Chaetoceros sp. TG07-C28 culture was inoculated with $5 \mathrm{~mL}$ of the virus suspension, and lysed. The lysate was passed through $0.4 \mu \mathrm{m}$ pore size polycarbonate membrane filters (Whatman Ltd., Kent, UK) to remove cellular debris. Polyethylene glycol 6000 (Wako Pure Chemical Industries Ltd., Osaka, Japan) was added to the filtrate to obtain a final concentration of $10 \%(\mathrm{w} / \mathrm{v})$, and the suspension was stored at $4^{\circ} \mathrm{C}$ in the dark, overnight. After centrifugation at $57,000 \times g$ at $4^{\circ} \mathrm{C}$ for $1.5 \mathrm{~h}$, the pellet was washed with $10 \mathrm{mM}$ phosphate buffer ( $\mathrm{pH}$ 7.2), and added to an equal volume of chloroform. After vigorous vortexing, the suspension was centrifuged at $2,200 \times g$ for $20 \mathrm{~min}$ at room temperature to remove the chloroform. The water phase was pipetted off and centrifuged at $217,000 \times g$ for $4 \mathrm{~h}$ at $4^{\circ} \mathrm{C}$ to collect the virus particles. The resultant viral pellets were used for genome analysis. The virus particles were resuspended in $600 \mu \mathrm{L}$ of ultrapure water, i.e., virus suspension, for use in viral protein analysis and negative staining observations under transmission electron microscopy (TEM).

\section{Viral proteins}

Aliquot $(5 \mu \mathrm{L})$ of the virus suspension was mixed with 4 volumes of denaturing sample buffer $(62.5 \mathrm{mM}$ Tris- $\mathrm{HCl}$ [pH 6.8], 5\% 2-mercaptoethanol, 2\% sodium dodecyl sulfate [SDS], $20 \%$ glycerol, and $0.005 \%$ bromophenol blue), and boiled for $5 \mathrm{~min}$. The proteins were then separated by SDS-polyacrylamide gel electrophoresis $(80 \times 40 \times 1 \mathrm{~mm}$, $12.5 \%$ polyacrylamide, $150 \mathrm{~V}$ ) using the XV Pantera Sys- 
tem (DRC Co. Ltd., Tokyo, Japan). Proteins were visualized using Coomassie brilliant blue stain. Protein molecular mass standards (Bio-Rad Laboratories Inc., Hercules, CA, USA) ranging from 10 to $250 \mathrm{kDa}$ were used for size calibration.

\section{TEM}

An exponentially growing culture of Chaetoceros sp. TG07-C28 was inoculated with the virus suspension $(5 \%$ $\mathrm{v} / \mathrm{v}$; multiplicity of virus infection, 100). As the control, a Chaetoceros sp. TG07-C28 culture was inoculated with autoclaved culture medium SWM3. An aliquot of the cell suspension was sampled at $48 \mathrm{~h}$ post-inoculation (hpi), and fixed with $2 \%$ glutaraldehyde and $3 \%$ paraformaldehyde in $0.1 \mathrm{M}$ cacodylate buffer ( $\mathrm{pH} 7.2$ ) containing $2 \% \mathrm{NaCl}$ for $2 \mathrm{~h}$ at $4^{\circ} \mathrm{C}$. Then, cells were collected by centrifugation, washed with $0.1 \mathrm{M}$ cacodylate buffer $(\mathrm{pH}$ 7.2) containing $2 \% \mathrm{NaCl}$ for $2 \mathrm{~h}$ at $4^{\circ} \mathrm{C}$, and embedded in $1 \%$ agarose, Type IX (Sigma-Aldrich Inc., St Louis, MO, USA). Washed samples were post-fixed with $2 \% \mathrm{OsO}_{4}$ in $0.1 \mathrm{M}$ cacodylate buffer $(\mathrm{pH} 7.2)$ containing $2 \% \mathrm{NaCl}$. After washing with buffer, the samples were dehydrated in a graded acetone series, and then they were embedded in Spurr's epoxy resin on aluminum foil dishes. Samples were polymerized for $12 \mathrm{~h}$ at $70^{\circ} \mathrm{C}$. Seventy $\mathrm{nm}$ thin sections were cut using a diamond knife on a Reichert Ultracut R microtome (Leica, Wetzlar, Germany), and mounted on formvar-coated oneslot grids. Sections were stained with $4 \%$ uranyl acetate and 3\% lead citrate, and observed with a JEM-1010 electron microscope (JEOL Ltd., Tokyo, Japan).

The virus particles that were negatively stained with uranyl acetate were also observed using transmission electron microscopy. Briefly, a drop of purified virus suspension was mounted on a grid (no. 780111630; JEOL Ltd., Tokyo, Japan) for $30 \mathrm{sec}$, and excess water was removed using filter paper (no. 1; Advantec MFS Inc., Tokyo, Japan). Then, $4 \%$ uranyl acetate was applied for $10 \mathrm{sec}$, and excess dye was removed using filter paper. After the grid was dried in a desiccator for $>2 \mathrm{~h}$, the negatively stained virus particles were observed using TEM at $80 \mathrm{kV}$. Particle diameters were estimated using the negatively stained images.

\section{Viral nucleic acids}

Nucleic acids were extracted from the viral pellet using the DNeasy Mini Kit (Qiagen K.K., Tokyo, Japan). Further, aliquots $(7 \mu \mathrm{L})$ of the nucleic acid solution were digested with RNase A (Nippon Gene Co. Ltd., Tokyo, Japan) at $0.025 \mu \mathrm{g} \mu \mathrm{L}^{-1}$ for $1 \mathrm{~h}$ at $37^{\circ} \mathrm{C}$, or incubated with DNase I (Takara Bio Inc., Otsu, Japan) at $0.5 \mathrm{U}_{\mu} \mathrm{L}^{-1}$ for $1 \mathrm{~h}$ at $37^{\circ} \mathrm{C}$, or with $\mathrm{S} 1$ nuclease (Takara Bio Inc., Otsu, Japan) at $0.7 \mathrm{U} \mu \mathrm{L}^{-1}$ for $15 \mathrm{~min}$ at $23^{\circ} \mathrm{C}$. Nucleic acid extracts kept on ice without treatment served as controls. The prepared nucleic acid samples were electrophoresed in agarose gels (1.2\%; SeaKem ${ }^{\circledR}$ GTG Agarose, Lonza Inc., Basel, Switzerland) at $50 \mathrm{~V}$ for $2.5 \mathrm{~h}$. Nucleic acids were visualized using SYBR-Gold staining (Molecular Probes Inc., Eugene, OR, USA).

\section{Genome sequencing}

The sequencing of a partial viral genome was performed using the random amplified polymorphic DNA (RAPD) method. In brief, RAPD-PCR amplification was conducted using a GeneAmp PCR System 9700 (Life Technologies Inc., Tokyo, Japan) with $50 \mu \mathrm{L}$ mixtures containing $<500$ ng viral template DNA, $1 \times$ KOD FX buffer (Toyobo Co. Ltd., Osaka, Japan), each deoxynucleoside triphosphate (dNTP) at a concentration of $200 \mathrm{nM}, 10 \mu \mathrm{M}$ random deca nucleotides (BT set, Takara Bio Inc., Otsu, Japan), and $1 \mathrm{U}$ of KOD FX DNA polymerase. The following cycle parameters were used for PCR: first, 5 rounds [denaturation at $94^{\circ} \mathrm{C}(30 \mathrm{sec})$, annealing at $30^{\circ} \mathrm{C}(30 \mathrm{sec})$, and extension at $68^{\circ} \mathrm{C}(5 \mathrm{~min})$ ]; second, 5 rounds [denaturation at $94^{\circ} \mathrm{C}(30 \mathrm{sec})$, annealing at $35^{\circ} \mathrm{C}(30 \mathrm{sec})$, and extension at $68^{\circ} \mathrm{C}(5 \mathrm{~min})$ ]; third, 5 rounds [denaturation at $94^{\circ} \mathrm{C}$ $(30 \mathrm{sec})$, annealing at $40^{\circ} \mathrm{C}(30 \mathrm{sec})$, and extension at $68^{\circ} \mathrm{C}$ $(5 \mathrm{~min})$ ]; fourth, 5 rounds [denaturation at $94^{\circ} \mathrm{C}(30 \mathrm{sec})$, annealing at $45^{\circ} \mathrm{C}(30 \mathrm{sec})$, and extension at $\left.68^{\circ} \mathrm{C}(5 \mathrm{~min})\right]$; and fifth, 15 rounds [denaturation at $94^{\circ} \mathrm{C}(30 \mathrm{sec})$, annealing at $50^{\circ} \mathrm{C}(30 \mathrm{sec})$, and extension at $\left.68^{\circ} \mathrm{C}(5 \mathrm{~min})\right]$. The PCR products were electrophoresed in $1 \%(\mathrm{w} / \mathrm{v})$ Agarose ME gels (Wako Pure Chemical Industries Ltd., Osaka, Japan), in which the nucleic acids were visualized by ethidium bromide staining. The fragments at $0.5-3.0 \mathrm{kbp}$ were excised from the gel using Quantum Prep Freeze 'N Squeeze $^{\mathrm{TM}}$ DNA Gel Extraction Spin Columns (Bio-Rad Laboratories Inc., Hercules, CA, USA), then purified using phenol-chloroform extraction, and dissolved in ultrapure water. The selected RAPD fragments were treated with r-Taq DNA polymerase (Takara Bio Inc., Otsu, Japan) in the presence of dATP according to the manufacturer's recommendation, then incubated at $70^{\circ} \mathrm{C}$ for $1 \mathrm{~h}$, and cloned using a TA cloning system (Life Technologies Inc., Tokyo, Japan). PCR products were ligated into a TOPO pCRII vector and transformed in Escherichia coli DH5a-competent cells (Toyobo Co. Ltd., Osaka, Japan). Sequencing was conducted using the dideoxy method with an ABI PRISM 3100 Genetic Analyzer (Life Technologies Inc., Tokyo, Japan). The resultant fragment sequences were reassembled using DNASTAR (DNASTAR Inc., WI, USA).

Southern blot analysis was conducted to distinguish the viral $(+)$ and complementary $(-)$ strand of the singlestranded region of the viral genomic DNA. On the basis of the predicted partial sequence, digoxigenin-labelled RNA probes specific for either the viral or complementary strand were transcribed from the constructed plasmid with T7 RNA polymerase or T3 RNA polymerase, respectively, according to the manufacturer's protocols (Promega K.K., Tokyo, Japan). The nucleotide sequence of the viral genome was determined by Southern dot-blot analysis using the probes according to a previously reported method (Mizumoto et al. 2007). The signals were detected with a 
luminescence image analyzer (LAS-3000 mini, Fuji Photo Film, Tokyo, Japan).

Putative open reading frames were identified using the ORF Finder (http://www.ncbi.nlm.nih.gov/gorf/gorf.html). Automated comparisons were conducted comparing the viral genome sequence using the BLAST program (Basic Local Alignment Research Tool, http://blast.ncbi.nlm.nih. gov/Blast.cgi) to genetic databases.

\section{Growth experiment}

An exponentially growing culture of Chaetoceros sp. strain TG07-C28 $(50 \mathrm{~mL})$ was inoculated at $15^{\circ} \mathrm{C}$ with the virus at a multiplicity of infection of 0.3 . A Chaetoceros sp. strain TG07-C28 culture inoculated with an autoclaved culture medium served as the control. An aliquot of the cell suspension was sampled from each culture at $0,12,24$, $30,36,48,60,72,84,96$, and $108 \mathrm{~h}$ post-inoculation (hpi), and the number of host cells and viral infectious units was estimated. This experiment was a single trial. Cell counts were carried out with Fuchs-Rosenthal hemocytometer using optical microscopy (TE-300, Nikon, Tokyo, Japan), without fixation of the samples. The number of viral infectious units was determined using the extinction dilution method (Suttle 1993). Briefly, the samples used to estimate the viral infectious units were passed through $0.8 \mu \mathrm{m}$ pore size polycarbonate membrane filters (Whatman Ltd., Kent, UK) to remove cellular debris. These filtrates were diluted with modified SWM3 medium in a series of 10-fold dilution steps. Aliquots $(100 \mu \mathrm{L})$ of each dilution were added to 8 wells in cell-culture plates with BD falcon 96 flat-bottom wells, and mixed with $150 \mu \mathrm{L}$ of exponentially growing culture of host algae. The cell culture plates were incubated at $15^{\circ} \mathrm{C}$ under a $12-\mathrm{h} \mathrm{L}: 12-\mathrm{h} \mathrm{D}$ cycle of 130 to $150 \mu \mathrm{M}$ photons $\mathrm{m}^{-2} \mathrm{sec}^{-1}$ with cool white fluorescent illumination, and were monitored over 14 days using optical microscopy (TE-300, Nikon, Tokyo, Japan) for the occurrence of culture lysis. Due to the virus infection, the culture lysis was usually observed as almost complete crashes of the host cell population in a well. We calculated virus abundance from the number of wells in which algal lysis occurred using BASIC program (Nishihara et al. 1986). The burst size was calculated by comparing the increase in infectious titer and decrease in host cell number.

\section{Results and Discussion}

\section{Isolation of the viral pathogen}

The viral isolate retained its lytic activity after filtration through a $0.2 \mu \mathrm{m}$ filter. The lytic activities were serially transferable to Chaetoceros sp. strain TG07-C28 cultures. The cytoplasm and photosynthetic pigments of virus-infected Chaetoceros sp. cells were degraded compared to healthy cells (Fig. 1).

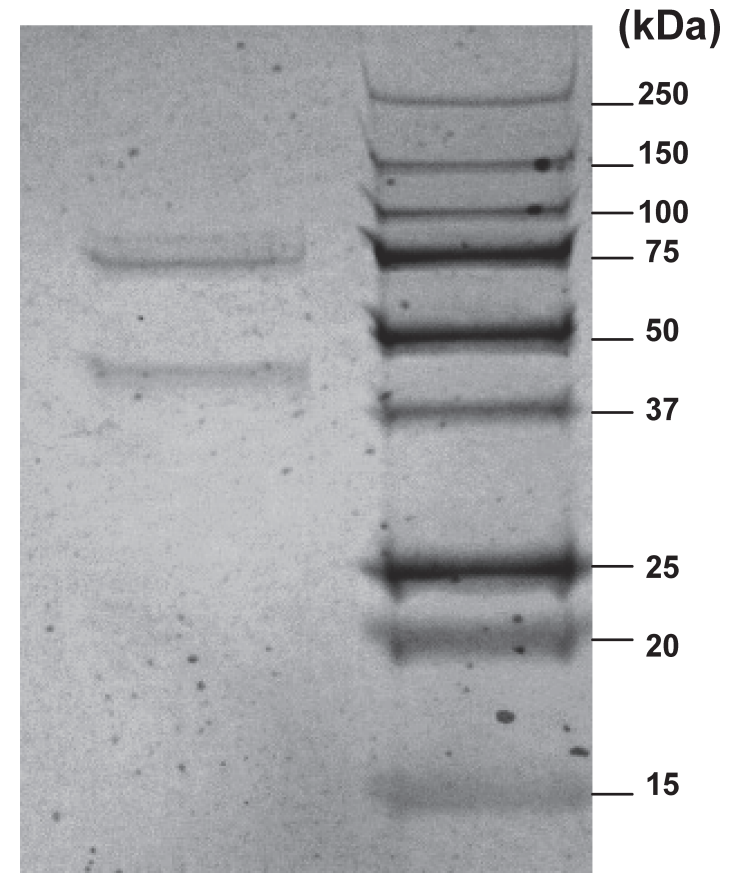

Fig. 2. Major structural proteins of Csp05DNAV visualized by sodium dodecyl sulfate-polyacrylamide gel electrophoresis.

\section{Host range}

The host range of the virus was tested using 28 phytoplankton strains, including 14 diatom strains. The virus was lytic to its original host Chaetoceros sp. strain TG07$\mathrm{C} 28$, but not to any other microalgal species that were tested (Table 1). These results show the high species-specific infection of this virus and this is a general feature of microalgal viruses.

\section{Proteins}

The results of sodium dodecyl sulfate-polyacrylamide gel electrophoresis revealed two major protein bands that had a molecular weight of 75 and $40 \mathrm{kDa}$, respectively, and one faint band with a molecular weight of $86 \mathrm{kDa}$ (Fig. 2). The gel electrophoresis pattern appeared to be different to that of other previously reported diatom DNA viruses, such as CsalDNAV, CdebDNAV, and CtenDNAV, infecting Chaetoceros salsugineum Takano (Nagasaki et al. 2005), Chaetoceros debilis Cleve (Tomaru et al. 2008) and Chaetoceros tenuissimus Meunier (Tomaru et al. 2011b), respectively. The major protein bands of these three viruses are located between 22 and $46 \mathrm{kDa}$ (Nagasaki et al. 2005, Tomaru et al. 2008, Tomaru et al. 2011b). Furthermore, ClorDNAV infecting Chaetoceros lorenzianus Grunow contains just a single major polypeptide of $225 \mathrm{kDa}$ (Tomaru et al. 2011c), which differed to that of the virus isolated in the present study.

\section{Morphological features}

Thin sections of healthy Chaetoceros sp. strain TG07- 

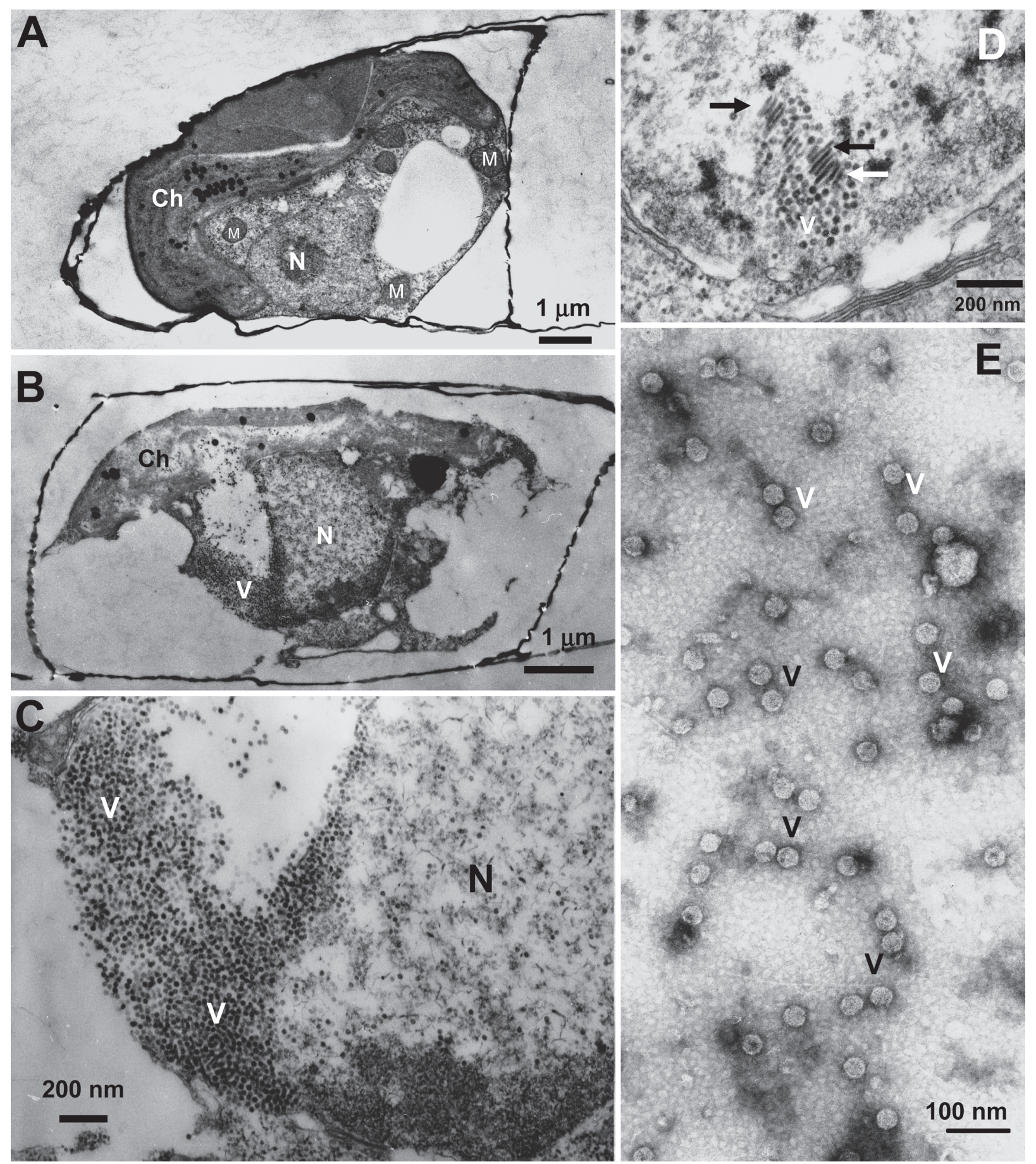

Fig. 3. Transmission electron micrographs of ultrathin sections of Chaetoceros sp. strain TG07-C28 and negatively stained Csp05DNAV particles. (A) Healthy cell. (B, C, D) Cells infected with Csp05DNAV at 48h post-inoculation. (B) Virus-like particles (VLPs) are accumulated in the host nucleus. (C) Higher magnification of the VLPs in the host nucleus of panel B. (D) Higher magnification of the VLPs in the host nucleus. Arrows indicate rod-shaped particles. (E) Negatively stained Csp05DNAV particles. Ch: chloroplast; M: mitochondrion; N: nucleus; V: virus-like particles.

C28 cells showed that the cytoplasmic organization and frustules are typical of these diatoms (Fig. 3A). In contrast, electron micrographs of thin-sectioned cells at $48 \mathrm{~h}$ post-inoculation (hpi) showed the presence of virus-like particles (VLPs) with a diameter of $32 \pm 2 \mathrm{~nm}(\mathrm{n}=30)$, which were randomly assembled in the host nucleus (Fig. 3B, C and D). VLPs were not found in healthy control cells (Fig. 3A). Furthermore, VLPs were also observed in culture lysates by negative staining electron microscopy (Fig. 3E). VLPs were hexagonal in outline, suggesting icosahedral symme- 
try. They were $34 \pm 1 \mathrm{~nm}(\mathrm{n}=30)$ in diameter, lacked a tail and outer membrane, and appeared similar to the VLPs observed in the host nucleus (Fig. 3C). Both the virion assemblage site and particle diameter were similar to that of ssDNA diatom viruses, CtenDNAV (Tomaru et al. 2011b) and ClorDNAV (Tomaru et al. 2011c). Since (i) the algicidal pathogen was transferable to a fresh algal culture, (ii) VLPs were observed in the lysed culture, and (iii) VLPs were not found in healthy cultures, we concluded that the 32-34 nm particles observed within the infected cells and in the algal lysates comprised a highly plausible virus that is pathogenic to Chaetoceros sp. strain TG07-C28. To date, four different ssDNA viruses that infect Chaetoceros species have been reported; specifically, CsalDNAV, CdebDNAV, CtenDNAV, and ClorDNAV (Nagasaki et al. 2005, Tomaru et al. 2008, Tomaru et al. 2011b, Tomaru et al. 2011c). The virus identified in this study is the fifth case of an ssDNA virus infecting the genus Chaetoceros. This new virus was tentatively designated as Chaetoceros sp. number 05 DNA virus (Csp05DNAV).

In addition to the VLPs of diameter $32 \mathrm{~nm}$, rod-shaped particles of $19 \pm 1 \mathrm{~nm}(\mathrm{n}=15)$ width were also observed in the host nucleus (Fig. 3D). Similar rod-shaped particles in the virus-infected host cells have been reported for other Chaetoceros viruses; specifically, CwNIV, CtenDNAV, and ClorDNAV (Eissler et al. 2009, Tomaru et al. 2011b, Tomaru et al. 2011c). Yet, rod shaped particles have not been observed in the viral lysate. Therefore, all of these studies indicate that these particles in the virus-infected host cells may be the precursors of mature virions. The rod-shaped particles in the infected host cells were not observed together with the icosahedral VLPs in the negatively stained viral suspensions, suggesting that the concentration of rod-shaped particles might be considerably lower or absent in the lysates. However, the alternative hypothesis that the rod-shaped particle is a co-infecting virus cannot be excluded. Further analyses are necessary to clarify the role of these particles, and their relationships to the icosahedral virions.

\section{Genomic analysis}

The intact Csp05DNAV genome exhibited two major bands (ca. $4.5 \mathrm{~kb}$ and $5.5 \mathrm{~kb}$ ) and two minor bands (ca. $0.6 \mathrm{~kb}$ and $1.0 \mathrm{~kb}$ ) of nucleic acids (Fig. 4A). All bands were sensitive to DNase I, but not to RNase A (Fig. 4B, lanes 1 and 2, respectively); therefore, the viral genome is considered to be DNA. In addition, the genome was digested with S1 nuclease; however, a double-stranded DNA (dsDNA) of $\sim 0.9 \mathrm{kbp}$ remained undigested (Fig. 4B, lane 3). In a preliminary PCR experiment using inverse PCR primer pairs, the size of the amplicon was similar to that of the Csp05DNAV genome (unpublished data), which indicates that the genome is a closed circular form (Tomaru et al. 2011b). These results are typical of a covalently closed circular ssDNA genome containing a partially double-stranded DNA region, as observed for previously reported circular

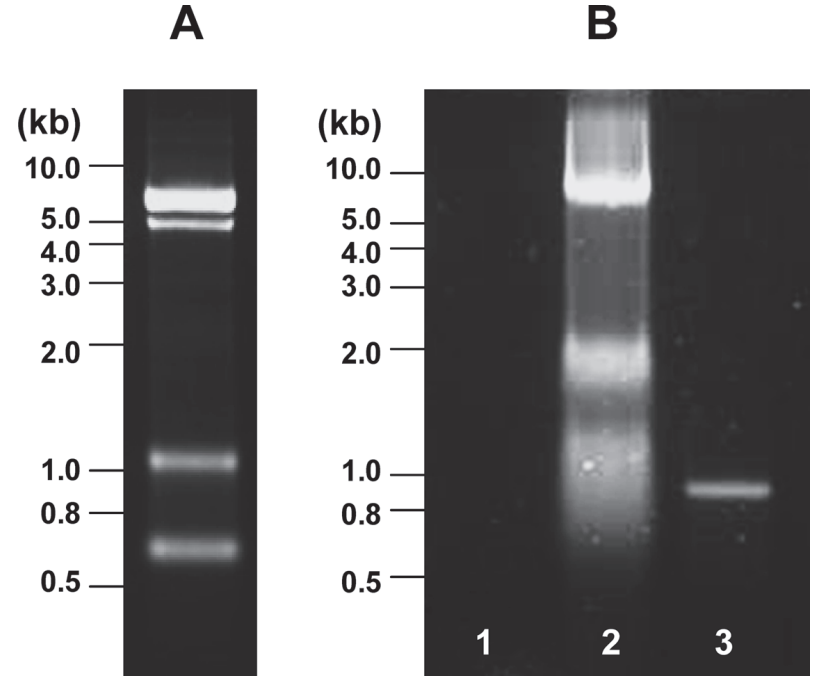

Fig. 4. Intact nucleic acids of Csp05DNAV (A), treatment with DNase I (B, lane 1), RNase A (lane 2), S1 nuclease (lane 3). Samples were electrophoresed in an agarose gel.

DNA diatom viruses (Tomaru et al. 2011c). Based on these data, we concluded that the viral genome consists of a single strand of covalently closed circular DNA that is partly double-stranded. The two minor bands are considered to be components of the virus genome; however, their features were not revealed in this study.

Partial sequencing of the Csp05DNAV genome and the Southern blot analysis identified 1,602 bases (AB647334) that included one open reading frame (ORF). This ORF contained 534 amino acids, and showed high similarity to the putative replication-associated protein of ClorDNAV (E-value $2 \mathrm{e}^{-153}$ ), CsalDNAV (E-value $3 \mathrm{e}^{-137}$ ), CtenDNAV (E-value $3 \mathrm{e}^{-115}$ ), and CdebDNAV (E-value $1 \mathrm{e}^{-59}$ ). Csp05DNAV is considered to be a member of the genus Bacilladnavirus, recently accepted as a genus by the International Committee on Taxonomy of Viruses, based on the present results, including the genome type, structure, and sequences. Other than these diatom viruses, no viruses infecting marine micro-organisms were similar to Csp05DNAV. The ORF of Csp05DNAV showed low similarity with the replication protein of goose circovirus (E-value $1 \mathrm{e}^{-4}$ ) and the replication-associated protein of beak and feather disease virus (E-value $1 \mathrm{e}^{-4}$ ), both of which belong to ssDNA viruses of the family Circoviridae and genus Circovirus (Todd et al. 2000).

\section{Replication}

Chaetoceros sp. strain TG07-C28 grew exponentially for $36 \mathrm{~h}$ in both control and virus-added cultures; however, the cell number in the inoculated culture rapidly decreased after $48 \mathrm{~h}$ post-inoculation (hpi) (Fig. 5). The first significant increase in virus abundance was also observed at 24 hpi (Fig. 5); thus, the latent period of Csp05DNAV appeared to be $<24 \mathrm{~h}$. This discrepancy, whereby there is a 


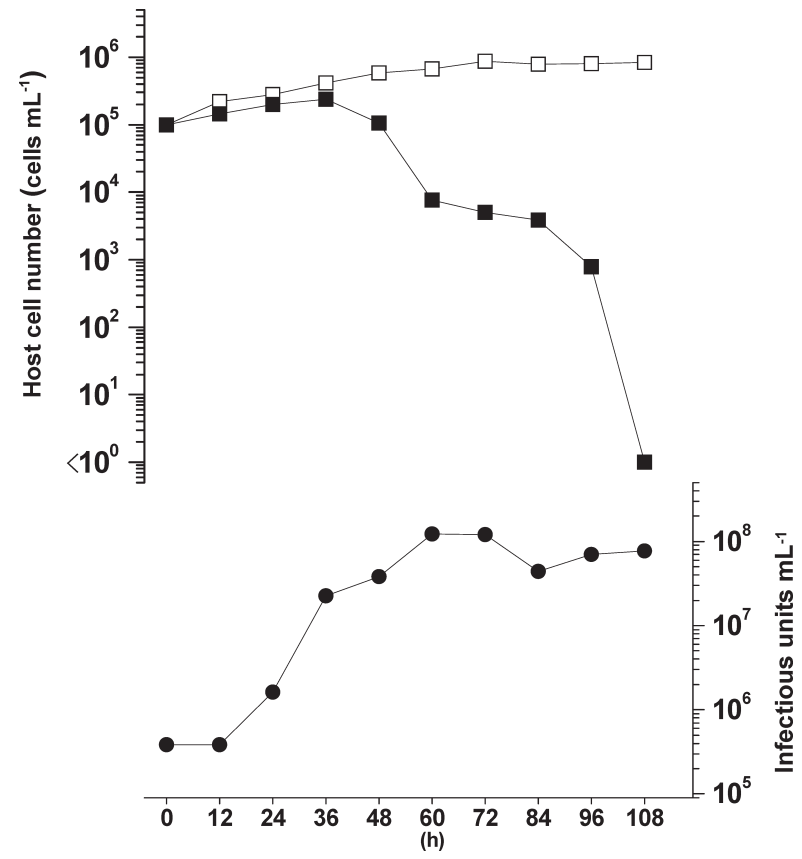

Fig. 5. Changes in cell number of Chaetoceros sp. strain TG07-C28 used for growth experiments with ( $\square$ ) or without $(\square)$ virus Csp05DNAV inoculation, and the virus titer $(\mathbf{O})$. The number of host cells and viruses were estimated by direct counting using microscopy and the extinction dilution method, respectively. Virus inoculation was performed at 0 days in an exponentially growing host culture with a multiplicity of infection of 0.3 .

parallel increase in host and virus numbers, is commonly observed in diatom host-virus systems (Shirai et al. 2008, Tomaru et al. 2011b). This is considered to occur due to a low percentage of virus sensitive cells being present during the logarithmic growth phase of the host populations, the numbers of which might increase during a stationary phase.

The average hosts/virus ratio at 36 to $60 \mathrm{hpi}$ was used to calculate the burst size, which was estimated to be $4.3 \times$ $10^{2}$ infectious units cell ${ }^{-1}$. The burst sizes of the previously reported ssDNA diatom viruses range between $\sim 10^{1}-10^{2}$ infectious units cell ${ }^{-1}$ except for that of ClorDNAV, at $\sim 10^{4}$ infectious units cell ${ }^{-1}$ (Tomaru \& Nagasaki 2011, Tomaru et al. 2011b, 2011c). The diversities of the burst sizes might reflect the differences of the ecological strategies for each ssDNA virus species. The burst size of the viruses should be determined under various environmental conditions, e.g. nutrients, salinity and temperature, to reveal the effects of the diatom viruses on the host population dynamics in future studies.

\section{Ecological implications}

Both the host species and the virus Csp05DNAV were isolated from Ago Bay, Japan. Because the virus was isolated from the sediments, the bottom sediments may serve as a reservoir for the virus throughout the year, as previ- ously reported for the relationship between Heterocapsa circularisquama Horiguchi (Dinophyceae) and its infectious virus HcRNAV in Ago Bay (Tomaru et al. 2007). HcRNAV specifically increases its abundance in sediments during the host blooming periods, and survives within the sediment layer until the next bloom the following year. The temperature stability of the diatom ssDNA virus group is high (Tomaru et al. 2008, Tomaru et al. 2011b). In addition, Csp05DNAV was stably preserved for long periods of at least one year at temperatures below $4^{\circ} \mathrm{C}$ (unpublished data). In Ago Bay, the host-virus relationship between Chaetoceros sp. strain TG07-C28 and Csp05DNAV is likely to have been established and maintained over a long period of time. For further understanding of their ecological relationships in nature, developments of host speciesspecific detection and quantification methods such as using real-time PCR (Toyoda et al. 2010) are necessary, because the microscopic detection and abundance determination of Chaetoceros sp. strain TG07-C28 in natural waters will be considerably difficult.

The relationship between Chaetoceros dynamics and its infectious viruses in natural environments is being gradually revealed. The diatom viruses in the water column rapidly increase during their host diatom blooms, C. tenuissimus and $C$. debilis, and are maintained at a high abundance throughout the blooming period (Tomaru et al. 2011a). Diatom populations appear to be affected by their infectious viruses, even when both host and virus concentrations are relatively low (Tomaru et al. 2011a). Recent studies have also shown that two distinctive viruses (i.e., CtenRNAV and CtenDNAV) can share the same diatom species $C$. tenuissimus and might simultaneously affect the host population dynamics (Tomaru et al. 2011b). These observations suggest that diatom viruses affect their respective host population dynamics in natural environments.

The genus Chaetoceros is one of the major phytoplankters in the ocean and plays an important role as primary producers (Rines \& Hargraves 1988). This genus includes at least 400 species, and blooms of Chaetoceros are often composed of multiple species, with one example exceeding 15 species (Rines \& Hargraves 1988). Many recent reports on the isolation of Chaetoceros viruses, e.g. reviewed in Tomaru \& Nagasaki (2011), suggest that the population dynamics of each species might be affected by its infectious viruses. To reveal further the dynamics of Chaetoceros populations and associated viral effects, the isolation and characterization of new diatom viruses should be continued.

\section{Acknowledgements}

This study was supported by Grants-in-Aid for Young Scientists (A) (22688016) from the Ministry of Education, Science, and Culture of Japan. 


\section{References}

Chen LCM, Edelstein T, McLachlan J (1969) Bonnemaisonia hamifera Hariot in nature and in culture. J Phycol 5: 211-220.

Eissler Y, Wang K, Chen F, Wommack E, Coats W (2009) Ultrastructural characterization of the lytic cycle of an intranuclear virus infecting the diatom Chaetoceros $\mathrm{cf}$. wighamii (bacillariophyceae) from Chesapeake Bay, USA. J Phycol 45: 787-797.

Geider RJ, MacIntyre HL, Kana TM (1988) A dynamic regulatory model of phytoplanktonic acclimation to light, nutrients, and temperature. Limnol Oceanogr 43: 679-694.

Itoh K, Imai I (1987) Rafido so [Raphidophyceae]. In: A Guide for Studies of Red Tide Organisms (ed Japan Fisheries Resource Conservation Association). Shuwa, Tokyo, pp. 122130. (in Japanese)

Kooistra WHCF, Gersonde R, Medlin LK, Mann DG (2007) The origin and evolution of the diatoms: Their adaptation to a planktonic existence. In: Evolution of Primary Producers in the Sea (eds Falkowski PG, Knoll A). Elsevier, San Diego, pp. 207-249.

Mizumoto H, Tomaru Y, Takao Y, Shirai Y, Nagasaki K (2007) Intraspecies host specificity of a single-stranded RNA virus infecting a marine photosynthetic protist is determined at the early steps of infection. J Virol 81: 1372-1378.

Nagasaki K, Tomaru Y, Takao Y, Nishida K, Shirai Y, Suzuki H, Nagumo T (2005) Previously unknown virus infects marine diatom. Appl Environ Microbiol 71: 3528-3535.

Nelson DM, Treguer P, Brzezinski MA, Leynaert A, Queguiner B (1995) Production and dissolution of biogenic silica in the ocean: Revised global estimates, comparison with regional data and relationship to biogenic sedimentation. Global Biogeochem Cycles 9: 359-372.

Nishihara T, Kurano N, Shinoda S (1986) Calculation of most probable number for enumeration of bacteria on microcomputer. Eisei Kagaku 32: 226-228. (in Japanese with English abstract)

Rines JBE, Hargraves PE (1988) The Chaetoceros Ehrenberg (Bacillariophyceae) flora of Narragansett Bay, Rhode Island, USA. Bibl Phycol 79: 1-196.

Sarthou G, Timmermans KR, Blain S, Treguer P (2005) Growth physiology and fate of diatoms in the ocean: a review. J Sea Res 53: 25-42.

Shirai Y, Tomaru Y, Takao Y, Suzuki H, Nagumo T, Nagasaki K (2008) Isolation and characterization of a single-stranded RNA virus infecting the marine planktonic diatom Chaetoceros tenuissimus Meunier. Appl Environ Microbiol 74: 40224027.

Suttle CA (1993) Enumeration and isolation of viruses. In: Hand- book of Methods in Aquatic Microbial Ecology (eds Kemp PF, Sherr E, Cole JJ). Lewis Publishers, Boca Raton, pp. 121-137.

Todd D, McNulty MS, Mankertz A, Lukert P, Randels JW, Dale JL (2000) Family Circoviridae. In: Virus Taxonomy, Classification, and Nomenclature of Viruses, 7th report (eds Van Regenmortel MHV, Fauquet CM, Bishop DHL, Carsten EB, Estes MK, Lemon SM, Maniloff J, Mayo MA, McGeoch DJ, Pringle CR, Wickner RB). Academic Press, San Diego, pp. 299-303.

Tomaru Y, Fujii N, Oda S, Toyoda K, Nagasaki K (2011a) Dynamics of diatom viruses on the western coast of Japan. Aquat Microb Ecol 63: 223-230.

Tomaru Y, Hata N, Masuda T, Tsuji M, Igata K, Masuda Y, Yamatogi T, Sakaguchi M, Nagasaki K (2007) Ecological dynamics of the bivalve-killing dinoflagellate Heterocapsa circularisquama and its infectious viruses in different locations of western Japan. Environ Microbiol 9: 1376-1383.

Tomaru Y, Nagasaki K (2011) Diatom viruses. In: The Diatom World, Cellular Origin, Life in Extreme Habitats and Astrobiology vol 19 (eds Seckbach J, Kociolek JP). Springer, London, pp. 211-225.

Tomaru Y, Shirai Y, Suzuki H, Nagumo T, Nagasaki K (2008) Isolation and characterization of a new single-stranded DNA virus infecting the cosmopolitan marine diatom Chaetoceros debilis. Aquat Microb Ecol 50: 103-112.

Tomaru Y, Shirai Y, Toyoda K, Nagasaki K (2011b) Isolation and characterisation of a single-stranded DNA virus infecting the marine planktonic diatom Chaetoceros tenuissimus Meunier. Aquat Microb Ecol 64: 175-184.

Tomaru Y, Takao Y, Suzuki H, Nagumo T, Koike K, Nagasaki K (2011c) Isolation and characterization of a single-stranded DNA virus infecting Chaetoceros lorenzianus Grunow. Appl Environ Microbiol 77: 5285-5293.

Tomaru Y, Tarutani K, Yamaguchi M, Nagasaki K (2004) Quantitative and qualitative impacts of viral infection on Heterosigma akashiwo (Raphidophyceae) population during a bloom in Hiroshima Bay, Japan. Aquat Microb Ecol 34: 227-238.

Toyoda K, Nagasaki K, Tomaru Y (2010) Application of realtime PCR assay for detection and quantification of bloomforming diatom Chaetoceros tenuissimus Meunier. Plankton Benthos Res 5: 56-61.

Toyoda K, Nagasaki K, Williams DM, Tomaru Y (2011) PCRRFLP analysis for species-level distinction of the genus Chaetoceros Ehrenberg (Bacillariophyceae). Hiyoshi Rev Natur Sci 50: 21-30.

Yokoyama K, Ueda H (1997) A simple corer set inside an Ekman grab to sample intact sediments with the overlying water. Benthos Res 52: 119-122. 